Andrzej Ostrowski

Uniwersytet Marii Curie-Skłodowskiej, Lublin

ORCID: 0000-0001-8374-6884

e-mail: ostrowski.a@poczta.umcs.lublin.pl

\title{
"Ja" jako pierwszy i jedyny przykład bytu samego w sobie i dla siebie
}

DOI: http://dx.doi.org/10.12775/RF.2019.002

Polemika Stanisława Ignacego Witkiewicza (dalej: Witkacy) z solipsyzmem, a w szerszym ujęciu również z idealizmem jako źródłem solipsyzmu, była wielowątkowa i - niestety - nie zawsze spójna, co można tłumaczyć tym, że Witkacy nie był w pełni zadowolony z przytaczanych przez siebie argumentów przeciwko solipsyzmowi. Nie dbając o zgodność wywodu, wciąż poszukiwał nowych. Widać to wyraźnie przy zestawieniu dwóch rozpraw poświęconych próbie przezwyciężenia solipsyzmu: Dodatku do krytyki Whiteheada przez Metallmanna (Dodatek opatrzony jest podtytułem: Próba dowodu niemożności przyjęcia solipsyzmu i radykalnego idealizmu ontologicznego (dalej: Krytyka)) i Traktatu o bycie samym w sobie $i$ dla siebie (dalej: Traktat). Obie prace stanowią względną całość, ponieważ w Traktacie Witkacy poczynił szereg odniesień do wcześniejszych ustaleń zawartych w Krytyce. Nie wszystkie rozwiązania przedstawione w tych rozprawach dadzą się jednak z sobą pogodzić.

Można polemizować z różnymi argumentami przytaczanymi przez Witkacego przeciwko solipsyzmowi i idealizmowi, zastanawiać się nad ich spójnością, wagą i trafnością. W kontekście prowadzonej przez Witkacego polemiki z solipsyzmem szczególnie interesujące jest rozwiązanie wprowadzone w Traktacie, które - to teza interpretacyjna - uniemożliwia przełamanie solipsyzmu.

Rozważenie tego zagadnienia wymaga w pierwszej kolejności zwrócenia uwagi na wymienione przez Witkacego rodzaje solipsyzmu i ich charakterystyki oraz na sformułowane $\mathrm{w}$ stosunku do nich wybrane zarzuty. 


\section{Jaki solipsyzm?}

Witkacy w Krytyce wyróżnił dwa rodzaje solipsyzmu: ${ }^{1}$ a) solipsyzm czysto-jaźniowo-punktalny, b) solipsyzm jaźniowo-cielesny. W Traktacie wymienia natomiast, w niektórych przypadkach tylko zdawkowo: solipsyzm spirytualistyczny, solipsyzm duchowy, solipsyzm jaźniowy, solipsyzm punktalno-jaźniowy, solipsyzm cielesny, solipsyzm jednocielesny czy też solipsyzm ontologiczny. Wprowadzona w Traktacie poszerzona nomenklatura miała na celu między innymi zwrócenie uwagi na specyfikę omawianego danego rodzaju solipsyzmu, przy czym Witkacy często używał nowych zwrotów zamiennie z już wcześniej wprowadzonymi. Dla potrzeb dalszych rozważań odwołam się do przyjętego w Krytyce pierwotnego rozróżnienia na dwa rodzaje solipsyzmu: a) solipsyzm czysto-jaźniowo-punktalny, b) solipsyzm jaźniowo-cielesny.

Wyróżniony w Krytyce solipsyzm jaźniowo-cielesny - przez Witkacego określany również jako cielesny - charakteryzuje się tym, że za rzeczywistość uznaje się jedynie naszą jaźń oraz ciało, natomiast ciała i jaźnie „Innych" oraz przedmioty martwe uznaje się za złudę². Witkacy ten rodzaj solipsyzmu stanowczo deprecjonował, twierdząc, że: „Ten niekonsekwentny solipsyzm połowiczny, wobec analogii ciała samodotykalnego z dotykanymi innymi przedmiotami, nie jest godny, aby się nim zajmować: jest to po prostu bzdura"3. Deprecjacja oparta jest na założeniu, że jeżeli jesteśmy jedynym realnym bytem cielesnym, to ze względu na swoją cielesność potrzebujemy powietrza do oddychania i pokarmu do odżywiania się, które zgodnie ze stanowiskiem solipsyzmu musiałyby jednak być - jak stwierdził Witkacy - urojeniem. Z racji tego, że ciało jest bytem skończonym w sensie konieczności posiadania początku i końca, a do swojego zaistnienia w sposób konieczny potrzebuje także przyczyny, to stojąc na stanowisku solipsyzmu konsekwentnie - zdaniem Witkacego - należałoby mówić również o konieczności urojonej matki i urojonej śmierci. Takiego rodzaju konkluzje Witkacy uznał za niedorzeczne, ale ostatecznym argumentem za odrzuceniem solipsyzmu jaźniowo-cielesnego (resp. cielesnego) jest to, że Istnienia Poszczególne (IPN) bez przyjęcia „ich pewnej koniecznej struktury biologicznej [...] byłyby w ogóle nie-do-pomyślenia" ${ }^{4}$.

1 Por. Stanisław Ignacy Witkiewicz, „Krytyka pracy Joachima Metallmanna o Alfredzie Whiteheadzie", w: Stanisław Ignacy Witkiewicz, Nauki ścisłe a filozofia i inne pisma filozoficzne (1933-1939), oprac. Maciej Dombrowski, Magdalena Bizior-Dombrowska (Warszawa: Państwowy Instytut Wydawniczy, 2014), 459-460.

2 Por. tamże, 460.

3 Tamże.

4 Tamże, 462. 
Witkacy poświęcił znacznie więcej uwagi solipsyzmowi czysto-jaźniowo-punktalnemu. Scharakteryzował go między innymi przez podkreślenie, że jest to solipsyzm, ,[...] w którym uznajemy ciało za nieistotną przyczepkę do jaźni, niczym nie lepszą od reszty rzeczy, czyli za taką samą jak i one złudę [... $]^{\prime \prime}$. W solipsyzmie czysto-jaźniowo-punktalnym podmiotem poznającym jest jaźń punktalna, czyli bezprzestrzenna (Witkacy używał również pojęcia nieprzestrzennego "Ja"), której odpowiednikiem w filozofii George'a Berkeleya jest substancja duchowa, a w filozofii Gottfrieda Wilhelma Leibniza monada. Odwołuję się do tych dwóch filozofów, ponieważ Witkacy, pisząc o solipsyzmie i idealizmie - mimo że w swych rozważaniach wzmiankował również o innych (np. Edmundzie Husserlu, Bertrandzie Russellu) - polemizował przede wszystkim z Berkeleyem, szukając zarazem odniesień do rozstrzygnięć, jakie można znaleźć w filozofii Leibniza.

Charakterystyka solipsyzmu czysto-jaźniowo-punktalnego pełni rolę przesłanki analizy krytycznej tego stanowiska, którą z kolei Witkacy wykorzystał do przeprowadzenia dowodu przeciwko solipsyzmowi. Witkacy, charakteryzując solipsyzm, nie powstrzymał się jednak od przedstawienia przy tej okazji własnego stanowiska. Jego zdaniem „,...] czysty duch jest fałszywą hipostaza, abstrakcją na tle niedokładnej analizy samych przeżyć" ${ }^{\prime \prime}$. Stanowisko Witkacego w kwestii „czystego ducha" jest istotne z tego względu, że w momencie jego wyartykułowania dalsze rozważania na temat przełamania solipsyzmu czysto-jaźniowo-punktalnego pozbawione są już sensu, ponieważ ten rodzaj solipsyzmu zakłada istnienie „czystego ducha”, czyli substancji duchowej. Pomimo tego zastrzeżenia przesłanką do kontynuowania autorskich rozważań jest wielokrotnie przytaczane przez Witkacego twierdzenie, że solipsyzm czysto-jaźniowo-punktalny jest konsekwentny i radykalny. Witkacy uznał go również za logicznie nieodparty, co oznacza, że solipsyzm ten jest pozbawiony „logicznej czysto sprzeczności"7. Zdaniem Witkacego nie oznacza to jednak, że ten rodzaj solipsyzmu jest niemożliwy do przełamania. Pisał: „łatwo jest czysto werbalnie i na podstawie nieprzenikliwości (ATN) [trwania same dla siebie jako takie - A.O.] stwierdzić solipsyzm jako nieodparty, opierając się o nieodpartość jego logiczną. Ale trudno go utrzymać, o ile zechce go się w jakiś możliwy ontologicznie sposób przeprowadzić" ${ }^{\prime 8}$.

\footnotetext{
5 Tamże, 459.

6 Tamże, 468.

7 Por. tamże, 460.

8 Tamże, 461.
} 


\section{Wyjść poza własny przykład}

Próbę wyjścia poza własny przykład Witkacy podjął w Traktacie9. Zaproponowane przez niego przełamanie solipsyzmu polegało na analizie tytułowego bytu samego w sobie $i$ dla siebie (BDŚ) oraz wyprowadzeniu konkluzji wskazujących na konieczność istnienia "Innego" podmiotu. Kluczowe rozwiązanie dla całokształtu tych rozważań zawarte jest już - moim zdaniem - w końcowym zachowanym fragmencie wstępu do Traktatu. Przy uwzględnieniu tytułowego pojęcia bytu samego w sobie $i$ dla siebie $\mathrm{z}$ kontekstu wypowiedzi zawartej w tym fragmencie można wyprowadzić wniosek, że prowadzący wywód - w Traktacie to Witkacy - jest „pierwszym i jedynym przykładem tego pojęcia” ${ }^{10}$. Wniosek ten przybiera formę tezy: "Ja" jestem pierwszym i jedynym przykładem pojęcia bytu samego w sobie $i$ dla siebie. Przyjęte przez Witkacego rozwiązanie stanowi przesłankę do sformułowania kolejnego zdania, w którym stwierdził: „Dalej dopiero, na podstawie analogii z innymi stworzeniami tego samego gatunku, a jeszcze dalej gatunków innych, dochodzę do przekonania, że inne żywe stwory są również pewnymi (BDŚN), które tak samo właśnie same w sobie i dla siebie istnieją jako i ja sam"11.

Abstrahując od problemów związanych z wnioskowaniem przez analogię, w ujęciu ogólnym pomysł Witkacego na przełamanie solipsyzmu jest prosty i polega na tym, że wychodząc w rozważaniach od "Ja" (od siebie) jako pierwszego i jedynego przykładu pojęcia bytu samego w sobie $i$ dla siebie, ostatecznie wnioskował on o istnieniu "Innych". Natomiast ze względu na posiadane określone wrażenia jakości, które - jak twierdził - są niesamodzielne, co oznacza, że wymagają substratu, Witkacy również wnioskował o istnieniu świata istniejącego niezależnie od "Ja". Potwierdza to między innymi kolejny fragment wypowiedzi, w którym Witkacy podkreślił zasadność punktu wyjścia rozważań:

Mając tę niesprowadzalną do niczego, najpierwotniejszą właściwość „bycia samych dla siebie” i właściwość jedyności jako takich właśnie, będąc wielościami elementów ostatecznych (jakości) wolnych jako takich od problemu podzielności przestrzennej i czasowej w nieskończoność,

9 Traktat nie zachował się w całości; więcej na ten temat zob. Maciej Dombrowski, "Nota wydawnicza”, w: Stanisław Ignacy Witkiewicz, Nauki ścisłe a filozofia i inne pisma filozoficzne (1933-1939), oprac. Maciej Dombrowski, Magdalena Bizior-Dombrowska (Warszawa: Państwowy Instytut Wydawniczy, 2014), 754-757.

10 Stanisław Ignacy Witkiewicz, "Traktat o bycie samym w sobie i dla siebie", w: Stanisław Ignacy Witkiewicz, Nauki ścisłe a filozofia i inne pisma filozoficzne (1933-1939), oprac. Maciej Dombrowski, Magdalena Bizior-Dombrowska (Warszawa: Państwowy Instytut Wydawniczy, 2014), 494.

11 Tamże. 
musimy uznać nas samych jako jedyny istotnie wylegitymowany punkt wyjścia dla opisu świata i nas w tym świecie, a wszelkie inne opisy opisać właśnie w funkcji tego naszego indywidualno-odśrodkowego na Istnienie spojrzenia ${ }^{12}$.

Przyjęte przez Witkacego rozwiązanie, pomimo składanych przez niego deklaracji, daje jednak podstawę do postawienia tezy interpretacyjnej, że przełamanie solipsyzmu jest niemożliwe. W celu uzasadnienia postawionej tezy przedmiotem dalszych analiz są dwa kluczowe elementy wypowiedzi Witkacego: „Ja” jako pierwszy przykład pojęcia (BDŚ), "Ja” jako jedyny przykład pojęcia (BDŚ).

Postawiona przez Witkacego teza, że "Ja" jestem pierwszym i jedynym przykładem pojęcia bytu samego w sobie i dla siebie, implikuje konieczność prowadzenia za Witkacym rozważań: a) zaczynając od "Ja"; b) „od środka", w przeciwieństwie do innej, wyróżnionej przez Witkacego formy rozpatrywania bytu „z boku” („z zewnątrz”) - „Pojęcia rozpatrywania: »od środka« $\mathrm{i}$ » boku«, są koniecznymi implikacjami pojęć: »bytu samego w sobie i dla siebie « $\mathrm{i}$ »bytu zjawiskowego «"13; c) w pierwszej osobie liczby pojedynczej. Trzeba przy tym zasygnalizować, że $\mathrm{w}$ tym przypadku Witkacy nie był konsekwentny, co ze względu na dwie pierwsze przesłanki wyjaśniam jego brakiem staranności w formułowaniu wypowiedzi.

Krytykowany przez Witkacego solipsyzm, jako stanowisko filozoficzne, również ma sens tylko wtedy, gdy rozważania na jego temat są prowadzone w pierwszej osobie liczby pojedynczej. Ta sama forma dociekań jest bardzo ważna dla podjętej próby przełamania solipsyzmu, ponieważ przy abstrahowaniu od przesłanek różnicujących filozofię Witkacego od szeroko pojętego solipsyzmu jest to wspólny element, dzięki któremu można mówić o faktycznie podjętej próbie przełamania tego stanowiska, a nie o jego krytyce z perspektywy innego stanowiska. Trzeba przy tym podkreślić, że taki sposób krytyki również był przez Witkacego stosowany. Ze względu na przyjęte przesłanki wyjściowe: "Ja" jako pierwszy przykład pojęcia (BDS), "Ja" jako jedyny przykład pojęcia (BDŚ) oraz ze względu na odwołanie się do analogii w celu wykazania istnienia Innego przełamanie solipsyzmu przez Witkacego sprowadza się do wyjścia poza własny przykład.

12 Tamże, 518-519.

13 Tamże, 506. 


\section{"Ja" jako pierwszy przykład pojęcia (BDŚ)}

Teza, że „Ja" jestem pierwszym przykładem pojęcia bytu samego w sobie i dla siebie, uniemożliwia przyjętemu hipotetycznie "Innemu" bycie pierwszym przykładem pojęcia (BDŚ). $Z$ tego wynika prosta konkluzja, że „Ja" jestem niezbędny do wykazania istnienia "Innego" (przy założeniu, że „Inny” w ogóle istnieje niezależnie od „Ja”). Jednak w chwili, gdy "Ja" jako pierwszy przykład pojęcia (BDŚ) przestaję istnieć (Witkacy zakładał, że "Ja" jest bytem, który powstaje i ginie, zatem jest bytem skończonym), tym samym zanika możliwość wykazania „Innego". W sensie poznawczym „Inny" przestaje istnieć wraz z „Ja” (przestaje istnieć wraz ze mną), ponieważ z perspektywy nieistniejącego "Ja" nie ma już możliwości nie tylko wykazania istnienia "Innego" (przy założeniu, że jest to w ogóle możliwe), ale również nie ma już możliwości przyjęcia tezy o hipotetycznym istnieniu „Innego".

\section{"Ja" jako jedyny przykład poięcia (BDŚ)}

Jeżeli „Ja" jestem jedynym przykładem pojęcia bytu samego w sobie i dla siebie, to - pomimo uwzględnienia analogii i założenia na jej podstawie możliwości mówienia o "Innych" bytach samych w sobie i dla siebie nie daję „Innym” możliwości mówienia w ten sam sposób, w jaki mówię o sobie, czyli mówienia o sobie jako bycie w sobie i dla siebie. "Ja" jestem przecież nie tylko "pierwszym”, ale i , jedynym przykładem tego pojęcia". Jeżeli jednak nie daje "Innym” możliwości mówienia w ten sam sposób, czyli nie daję możliwości, żeby każdy „Inny” mówił o sobie jako bycie w sobie i dla siebie, to tym samym nie daje "Innym" możliwości mówienia o "Innych”, ponieważ - według Witkacego - można tego dokonać tylko na zasadzie analogii, gdzie punktem wyjścia jestem "Ja" jako byt sam w sobie i dla siebie.

\section{Próba dowodu przeciwontologicznego}

Postawiona przez Witkacego teza: "Ja" jestem "pierwszym i jedynym przykładem" bytu samego w sobie i dla siebie nie jest lapsusem, który można zbagatelizować, lecz prostą konsekwencją jego stanowiska filozoficznego. Potwierdzają to nieco wcześniejsze rozważania Witkacego, do których odwołał się w Traktacie. Stwierdził w nich bowiem, że w logicznej nieodpartości solipsyzmu czysto-jaźniowo-punktalnego „,...] zawiera się pewna prawda, a mianowicie prawda o nieprzenikliwości wzajemnej dwóch jaźni, o ich absolutnej jedności, jedyności i płynącej stąd samot- 
ności wewnętrznej w Istnieniu"14. W cytowanej wypowiedzi druga jaźń była założona hipotetycznie, ponieważ na tym etapie rozważań Witkacy nie podjął jeszcze próby wykazania istnienia „Innego” (tu: drugiej jaźni). W wypowiedzi tej akcent położono natomiast na jedność jaźni, jej jedyność oraz samotność, co w pełni zostało wyrażone w tezie: "Ja" jestem "pierwszym i jedynym przykładem" bytu samego w sobie $i$ dla siebie. Konsekwencją przyjętego rozwiązania wyrażonego w przytoczonej tezie jest to, że „,...] zawsze mamy jedno (IP) [Istnienie Poszczególne - A.O.], które musimy rozpatrywać od środka, tj. od nas samych $[\ldots]^{\prime \prime 15}$.

Na podstawie przytoczonych dwóch ostatnich wypowiedzi można byłoby sądzić, że skoro zawsze mamy jedno (IP), od którego należy zacząć rozważania, i jako jedyne jest ono absolutną jednościa, to nie ma żadnej przesłanki, żeby wnioskować o wielości Istnień Poszczególnych (IPN). Konkluzja ta jest jednak sprzeczna ze stanowiskiem Witkacego, który do rozważań na temat wielości Istnień Poszczególnych przeszedł w zaskakująco prosty sposób, odwołując się do rozwiązań zawartych $\mathrm{w}$ fundamentalnej dla tworzonego systemu filozoficznego pracy Pojęcia i twierdzenia implikowane przez pojęcie Istnienia.

Tu, w tej właściwości (IP), w tym stanie rzeczy, że zawsze mamy jedno (IP), które musimy rozpatrywać od środka, tj. nas samych, a następnie wielość (IPN) w Rzeczywistej Przestrzeni (Istnienie bez wielości, jako absolutna jedność, jest nie-do-pomyślenia*), które jakoś muszą istnieć także dla tego rozpatrywanego od środka (IP), tkwi cała problematyka filozoficzna z jej głównymi zagadnieniami $[\ldots]^{16}$.

Odwołanie się przez Witkacego do wcześniejszych ustaleń przedstawionych w Główniaku, pomimo wykazania wielości Istnień Poszczególnych, nie rozwiązuje jednak problemu solipsyzmu. Uzasadnienie tej tezy ponownie wymaga prowadzenia rozważań w pierwszej osobie liczby pojedynczej: problem solipsyzmu nie jest rozwiązany, ponieważ Wielość Istnień Poszczególnych (IPN) w dalszym ciągu jest rozpatrywana w ramach danego Istnienia Poszczególnego, czyli w ramach "Ja", którego jestem pierwszym i jedynym przykładem z tą różnica, że jako podmiot uświadamiam sobie, że jestem bytem złożonym, a Istnienie Poszczegól-

14 Witkiewicz, „Krytyka”, 460.

15 Tegoż, „Traktat”, 495.

16 Tamże. W cytowanym fragmencie tekstu asterysk $\left({ }^{*}\right)$ jest oryginalnym indeksem przypisu. Witkacy odsyła w nim czytelnika do swojego Główniaka: Pojęcia i twierdzenia implikowane przez pojęcie Istnienia, w którym zagadnienie to jest szczegółowo omówione. 
ne bez wielości, Istnienie Poszczególne jako jedność Absolutna, jest nie do pomyślenia ${ }^{17}$.

Przedstawione ujęcie interpretacyjne omawianego zagadnienia pozwala stwierdzić, że Istnieniu Poszczególnemu przysługuje - lub też, mówiąc inaczej, towarzyszy na zasadzie współistnienia - Wielość Istnień Poszczególnych. Dla Witkacego w dalszych jego rozważaniach teza o współistnieniu wielości Istnień Poszczególnych była jedną z przesłanek przezwyciężenia solipsyzmu. Na tym etapie rozważań podkreślił on jednak, że wychodząc od "Ja", powstaje granica między "Ja" a „Innymi”, której nie sposób przekroczyć. „Na podstawie tego, że każde (IP) rozpatrywane »od środka « jako jego trwanie samo dla siebie jako takie = (AT) jest absolutnie $\mathrm{w}$ sobie, $\mathrm{w}$ tym trwaniu, zamknięte i nieprzenikalne, istnieje zawsze możliwość założenia solipsyzmu i idealizmu bez możności logicznego ich odparcia"18. Następnie Witkacy stwierdził, że według niego istnieje jednak dowód przeciwontologiczny ${ }^{19}$.

Witkacy w swoich rozważaniach doprowadził więc do sytuacji, w której z jednej strony mówił o braku możliwości logicznego odparcia solipsyzmu, z drugiej zaś przeciwstawiał dowód przeciwontologiczny na istnienie "Innych", który to dowód w jego mniemaniu przełamuje solipsyzm.

W dowodzie przeciwontologicznym Witkacy założył, między innymi, że podmiot jest bytem cielesnym, że wyjaśnienie jego istnienia wymaga odwołania się do biologicznej przyczyny, że procesy życiowe są możliwe dzięki fizycznym i niezależnym od podmiotu warunkom, że wrażenia, jakich doznaje podmiot, są niesamodzielne i wyjaśnienie ich istnienia wymaga odwołania się do substratu.

Rozważania prowadzone $\mathrm{w}$ ramach ontologii, nawet gdyby uznać zasadność i poprawność wszystkich argumentów przywoływanych przez Witkacego, nie znoszą jednak problemów wynikających z tego, że "Ja" jestem pierwszym i jedynym przyktadem bytu samego w sobie $i$ dla siebie, nie znoszą zatem tego, że bycie pierwszym i jedynym przykładem bytu samego w sobie i dla siebie uniemożliwia "Ja" (mi) wyjście poza własny przykład.

17 Zagadnienie niemożliwej do pomyślenia jedności Absolutnej jest złożonym problemem, a konkluzje przeprowadzonych rozważań na ten temat nie są takie oczywiste, jak przedstawia to Witkacy; por. Andrzej Ostrowski, „Konieczność nicości Absolutnej", w: Witkacy w kontekstach. Stanisław Ignacy Witkiewicz a kryzys metafizyki, red. Teresa Pękala (Lublin: Wydawnictwo UMCS, 2015), 47 i n.

18 Witkiewicz, „Traktat”, 496.

19 Por. tamże. 


\section{W świecie potworów i hybryd}

Otrzymanie mocnego stanowiska solipsyzmu z pewnością nie było zamysłem Witkacego, ale do takiej konkluzji prowadzi analiza jego wstępnych założeń. Wprowadzone rozwiązanie polegające na wnioskowaniu przez analogię z założenia powinno dać możliwość wykazania istnienia "Innego" oraz dać „Innemu” możliwość myślenia o sobie jako „Ja”, czyli bycie samym w sobie i dla siebie, a następnie możliwość myślenia o „Innych" w ten sam sposób. Z przeprowadzonych rozważań wynika, że takiej możliwości jednak nie ma.

Potwierdza to jeszcze jedno wprowadzone przez Witkacego rozwiązanie, które nawiązuje do wspomnianej już tezy, że o sobie samym, o "Ja", możemy mówić tylko „od środka". Tym razem chodzi o możliwość mówienia o tym, co hipotetycznie jest na zewnątrz podmiotu. Zdaniem Witkacego ze względu na wrażenia (doznania) i ich wspomnienia również o „Innym” możemy mówić „od środka”, chociaż „tym obserwowanym $» z$ boku « nie jesteśmy" ${ }^{20}$.

Wykazanie braku możliwości przełamania solipsyzmu nie dowodzi jednak, że „Inny" nie istnieje. W ujęciu interpretacyjnym - podobnie jak robił to Witkacy - można hipotetycznie przyjąć, że „Inny” istnieje i również jest bytem samym w sobie i dla siebie oraz - co najważniejsze - jest „pierwszym i jedynym przykładem tego pojęcia”.

Konsekwentnie można następnie przyjąć, że wszystkie hipotetycznie możliwe podmioty poznające myśla paralelnie o sobie jako o "Ja". Z przyjętych założeń wynika, że „Inny" (tu: każde pozostałe "Ja" rozpatrywane przez siebie samego) jest pierwszym przykładem pojęcia (BDŚ). Zaletą zaproponowanego sposobu interpretacji jest to, że w chwili, kiedy „Ja" przestaję istnieć, znika tylko mój świat, natomiast „Inny” (każde pozostałe "Ja" rozpatrywane przez siebie samego) może dalej hipotetycznie myśleć o „Innym” i podejmować próbę wykazania „Innego” i tym samym podejmować próbę przełamania solipsyzmu.

Dopuszczając taki tok rozumowania, powstaje $\mathrm{w}$ efekcie stanowisko, które w pewnym zakresie jest syntezą dwóch różnych, zmodyfikowanych na potrzebę interpretacji stanowisk filozoficznych: idealizmu subiektywnego Berkeleya oraz monadologii Leibniza. W ostatnim przypadku wielość monad jest założona u podstaw systemu, natomiast w pierwszym mowa o drugiej hipotetycznej substancji duchowej, która nie postrzega permanentnie. Hipotetyczne przyjęcie "drugiego" było Berkeleyowi potrzebne między innymi do tego, żeby wykazać istnienie substancji duchowej (Boga), która w przeciwieństwie do pierwszej sub-

20 Tamże, 502. 
stancji duchowej (,Ja") oraz drugiej substancji duchowej („,drugi”) postrzega permanentnie.

Do Berkeleya ponownie odwołuję się celowo, ponieważ w Traktacie Witkacy kierował krytyczne uwagi przeciwko solipsyzmowi przede wszystkim wprost do filozofii Berkeleya. Nie byłoby w tym nic szczególnego, gdyby nie to, że Witkacy podjął się próby przezwyciężenia solipsyzmu, wykorzystując przy tym rozwiązanie, jakie wprowadził Berkeley $^{21}$.

Stanowisko Witkacego, pomimo wspomnianej inspiracji w przezwyciężeniu solipsyzmu, jest jednak tylko podobne do stanowiska Berkeleya, ponieważ zasadnicza różnica między nimi polega na tym, że u Berkeleya podmiotem jest byt duchowy (w nomenklaturze Witkacego - czysta jaźń-punktalna), natomiast u Witkacego jest nim byt cielesny rozpatrywany jako jedność osobowości. Na tę jedność składają się kompleksy konieczne: przeżycia, ciało. Razem stanowią one realność pierwotna, jaką jesteśmy ${ }^{22}$. Wiąże się to bezpośrednio ze wspomnianym wcześniej dowodem przeciwontologicznym. Ważną kategorią dla właściwego pojęcia zagadnienia jedności osobowości jest „byt sam w sobie ciała”.

Musimy więc pomyśleć naszą osobowość przede wszystkim jako kompleks aktualnych jakości cielesnych, stanowiących jedność w Przestrzeni - i to nazywam bytem samym w sobie ciała. Do tego dochodzi wspomnienie tego ciała pozostające po każdej upływającej, minimalnie krótkiej chwili teraźniejszości [...], zlokalizowanych mniej lub więcej nieokreślenie w „byłym trwaniu", stanowi cielesną przeszłość (IP), będącą podstawą tego, co nazywamy bytem samym dla siebie, tj. bytem $\mathrm{w}$ trwaniu, w którym na tle całej przeszłości coraz mniej określonej rysuje się aktualny kompleks jakości cielesnych, przy czym w trwaniu obecnym może wystąpić mniej lub więcej dokładnie którakolwiek z chwil przeszłości; to stanowi podstawę do zjawiska "refleksji”, samooglądania (IP) $[\ldots]^{23}$.

Jeżeli konkluzja o niemożliwości wyjścia z solipsyzmu, jaka wynika z wprowadzonej przez Witkacego tezy, że "Ja" jest pierwszym i jedynym przykładem bytu samego w sobie $i$ dla siebie, zostanie uwzględniona i skorelowana z zagadnieniem jedności osobowości oraz teza, że byt ma naturę tylko cielesna, to w ujęciu interpretacyjnym można dojść do jeszcze bardziej skrajnego wniosku. Wyraża się on w stwierdzeniu, że solipsyzm, w jaki popada Witkacy z racji braku możliwości wyjścia poza własny przyktad, jest solipsyzmem cielesnym. Problem polega na tym, że Witka-

21 Na ten temat por. Andrzej Ostrowski, „Wspomnienia »Ja«, czyli o próbie przełamania solipsyzmu przez S. I. Witkiewicza", Rocznik Podhalański XI (Wokół Witkiewiczów) (2016), 303-319.

22 Por. Witkiewicz, ,Traktat”, 523.

23 Tamże, 504. 
cy - jak zostało to już zasygnalizowane - odrzuca ten rodzaj solipsyzmu, określając go jako „bzdurę"24.

Przy interpretacyjnej i tym razem celowo prowokującej hipotezie, że byt cielesny - o którym mówi Witkacy - jest redukowalny do niepodzielnego bytu cielesnego, można, uwzględniając konkluzję o solipsyzmie cielesnym, mówić o bycie jednocielesnym i konsekwentnie o solipsyzmie jednocielesnym. Jest to hipoteza prowokująca z dwóch powodów. Po pierwsze, odnosi się negatywnie do zasadniczej tezy Gtówniaka, na którą Witkacy powołuje się w Traktacie: „Istnienie bez wielości, jako absolutna jedność, jest nie-do-pomyślenia" ${ }^{25}$. Po drugie, podważa zasadność deprecjonującej oceny, jaką Witkacy wystawił solipsyzmowi jednocielesnemu, twierdząc, że jest „formą wprost idiotyczną"26.

W filozofii Witkacego w ujęciu metafizycznym drugie wynika z pierwszego, jednak teza o wielości istnienia nie jest tak oczywista, jak to sam zakładał, o czym była już wzmianka. Nie jest zatem wykluczone, że Witkacy, szukając argumentów przeciwko logicznie nieodpartemu solipsyzmowi czy to jaźniowo-punktalnemu, popada w rodzaj solipsyzmu, który z góry odrzucił jako „formę wprost idiotyczną”.

Witkacy zdawał sobie sprawę ze słabości budowanego przez lata stanowiska filozoficznego określanego mianem monadyzmu biologicznego (monadyzmu cielesnego). W rozważaniach poświęconych próbie przełamania solipsyzmu słabości te deprecjonuje w następujący sposób: „Wszystkie pozorne dziwności monadyzmu są niczym wobec powstania życia z przypadkowych zderzeń atomów w koncepcji materialistycznej, wobec bezprzestrzennej entelechii, wobec koszmaru świata idealistów. Za cenę monadyzmu cielesnego unikamy wszystkich tych pojęciowych potworów i hybryd"27.

Na podstawie przeprowadzonych rozważań trzeba jednak stwierdzić, że w przypadku próby przełamania solipsyzmu unikanie starych pojęciowych potworów i hybryd zakończyło się wprowadzeniem nowych.

\section{Bibliografia}

Dombrowski Maciej. 2014. „Nota wydawnicza”. W: Stanisław Ignacy Witkiewicz, Nauki ścisłe a filozofia i inne pisma filozoficzne (1933-1939). Oprac. Maciej Dombrowski, Magdalena Bizior-Dombrowska. 693-765. Warszawa: Państwowy Instytut Wydawniczy.

\footnotetext{
24 Por. Witkiewicz, „Krytyka”, 460.

25 Tegoż, „Traktat", 495.

26 Por. tamże, 496.

27 Tamże, 569.
} 
Ostrowski Andrzej. 2015. „Konieczność nicości Absolutnej”. W: Witkacy w kontekstach. Stanisław Ignacy Witkiewicz a kryzys metafizyki. Red. Teresa Pękala. 37-55. Lublin: Wydawnictwo UMCS.

Ostrowski Andrzej. 2016. „Wspomnienia »Ja«, czyli o próbie przełamania solipsyzmu przez S. I. Witkiewicza", Rocznik Podhalański XI: 303-319.

Witkiewicz Stanisław Ignacy. 2014. „Krytyka pracy Joachima Metallmanna o Alfredzie Whiteheadzie". W: Stanisław Ignacy Witkiewicz, Nauki ścisłe a filozofia i inne pisma filozoficzne (1933-1939). Oprac. Maciej Dombrowski, Magdalena Bizior-Dombrowska. 364-476. Warszawa: Państwowy Instytut Wydawniczy.

Witkiewicz Stanisław Ignacy. 2014. „Traktat o bycie samym w sobie i dla siebie". W: Stanisław Ignacy Witkiewicz, Nauki ścisłe a filozofia i inne pisma filozoficzne (1933-1939). Oprac. Maciej Dombrowski, Magdalena Bizior-Dombrowska. 494-569. Warszawa: Państwowy Instytut Wydawniczy.

\section{Streszczenie}

Celem rozważań jest wykazanie, że Stanisław Ignacy Witkiewicz, formułując zarzuty przeciwko solipsyzmowi, przyjął rozwiązanie, które - wbrew oczekiwaniom - uniemożliwia przełamanie solipsyzmu. W ten sposób ujawnia się problem udowodnienia, że „Inny” istnieje. Analizę tego problemu przeprowadzam na podstawie dwóch najważniejszych tekstów Witkiewicza dotyczących idealizmu i solipsyzmu.

Słowa kluczowe: solipsyzm, idealizm, Witkiewicz

\section{Summary}

\section{"I" as the First and the Sole Example of the Being in and for Itself}

The goal of the article is to discuss the problem of solipsism in Stanisław Ignacy Witkiewicz's philosophy. Witkiewicz intended to overcome the solipsism but, unfortunately, he accepted the solution which made this aim impossible. In this way, the problem with proving that "Other" exists appears. I perform the analysis of this problem on the basis of two main works by Witkiewicz on idealism and solipsism.

Keywords: solipsism, idealism, Witkiewicz 